\title{
Study and Simulation on Wind Storage Power Generation System Black Start Model
}

\author{
Gang Wang ${ }^{1,2}$, Jianchang Liu ${ }^{1}$, Li Liu ${ }^{2}$ and Yi Zhao ${ }^{2}$ \\ ${ }^{1}$ Northeastern University of China, Shenyang China \\ ${ }^{2}$ Shenyang Institute of Engineering, Shenyang China \\ 13889131662@163.com
}

\begin{abstract}
The wind Storage Power Generation System can not only smooth output fluctuation and improve the quality of electric energy, but also can be used as standby power of black start, the research direction is a new way to realize power grid black start. During the process of black start, the wind storage system has characteristics of output fluctuation and small system stable different from other controllable starting power. According to wind speed, load, storage energy data, the paper gives the criterion of black start implementation, through the control strategy of wind storage. the paper study the stability of the isolated system and black start system, and the proposed theory is verified. combined with the simulation example.
\end{abstract}

Keywords: Wind Storage Power Generation System; Black start; The criterion of black start; Control model

\section{Introduction}

The gradual dying of traditional energy makes the large-scaled accessing of new energies including wind power and solar power, etc gradually increase. Nevertheless, the fluctuation and intermittency of renewable energies bring new challenges to active power system operation and they need extra capacity to dynamically balance the output force of the renewable energies. The equipment with power storage equipment is a valid technology of solving the accessing of large-scaled renewable energies with power grid and they mainly function in the following aspects: smooth output force, track dispatch schedule, improve the predictable and economic performance of power generation through renewable energies, realize load shifting and thermal reserve and improve power energy quality. Besides, the matching use of large-capacity renewable energies and power storage function is able to provide the possibility of using renewable energies as black start power.

Black start is able to activate power units without self-start function in system failure without depending on the help of network based on the start of power units with self-start function to gradually expand system recovery range and finally realize the recovery of the entire system. As to black start scheme compilation, black start power focuses on hydropower unit and gas unit in power grid with the external connection with electric power and some small firepower units. According to characteristics of black start power, wind power storage system composed of power storage system and wind power system also contains the conditions for black start units. Currently, most black start abilities for new energy based power generation system are mostly based on expectation without any substantial development in the aspect of study in this field.

Document [1] discusses black start power's selection path based on specific condition in Tianjin Power Grid. It points out the treatment with black start power based on the difference of its origin and introduces the classification of black start subsystems and the 
path selection for black start in Tianjin Power Grid. It analyzes the influence on system stability caused by closing ring impact.

Document [2] confirms the black start power in power grid at provincial and municipal levels based on practical situation in Zhejiang Power Grid, analyzes problems including self excitation, over voltage and system stability, etc after black start power is initiated, and establishes black start scheme for Zhejiang Power Grid based on its practical situation.

Document [3] studies the black start scheme in Hechi Power Grid, analyzes and compares the two black start sub-schemes, confirms black start implementation scheme, analyzes and studies the problems in black start process, and studies problems including verification related to black start process and gradual system load recovery, etc.

Document [4] and Document [5] respectively study black start scheme Sudan Power Grid and Italian High-voltage Power Grid. In Document [6], experts conduct researches on black start in power grid. Document [7] specifically introduces black start principle and theoretical analysis in full power system failure.

Above all, domestic and foreign studies on black start mainly focus on start power selection, optimization of start path and relative stability, etc and the study on wind storage system's black start still stays in the initial phase. If we are able to realize study on wind storage system's black start, it is able to fill in the blank area in this aspect. Besides, it will provide richer choices of black start energies in power grid.

The study in this paper is based on wind storage power generation system with the use of large-scaled all-vanadium redox flow storage. It explores the technological plausibility and engineering plausibility of the black start scheme of this system in the areas and its content mainly include control technique path in wind storage power generation system, wind storage system power management and the compilation of power storage system control strategy and black start research scheme in wind storage system and the paper is able to provide a new direction for black start power in Northern area of Liaoning Province where there is short of both water and electric power.

\section{Characteristics of Wind Storage Power Generation System Black Start}

\subsection{Operating Characteristics of Wind Storage Power Generation System}

Wind storage system is able to sooth output force, utilize the active power coming out of wind storage system smooth fan based on change of wind power value and wind storage system capacity and realize no wind waste and relative output power stability in wind field.

\subsection{Black Start Stability of Isolated System}

When wind storage system is used as start power and started, it is also able to use fan start unit to constitute joint power system with wind storage. When one small isolated system is formed after the fan is started, storage system will finish system power balancing. Storage system will store the extra electric power output by the fan and the overall active power of the start fan shall not exceed the capacity of storage system. The wind storage system composed of fan and storage system shall be able to guarantee the stable operation of the isolated system.

\subsection{Stability of Isolated System with Load Impact}

After wind storage power generation system realizes isolated operation, whether or not the system is able to keep its stable operation in disturbance and load impact becomes the key technique in judging whether or not wind storage system is able to be used as black 
start power.

\section{Wind Storage Power Generation Black Start Model}

\subsection{Fan Model}

Double-fed Wind Power Generation System is able to use power control to realize maximum wind power capture in different wind speeds through adjusting blade pitch angle in wind turbine system. [8] Double-fed wind power generator is a wound induction motor with slipping ring in structure and it is directly connected with power grid in its stator side and it is connected with power grid in rotator side through one back-to-back converter system (converter in stator side and converter in grid side) and the aforesaid back-to-back converter system is able to realize motor control and the two-way power flow in rotator side.

Fan vector control diagram is as follows:

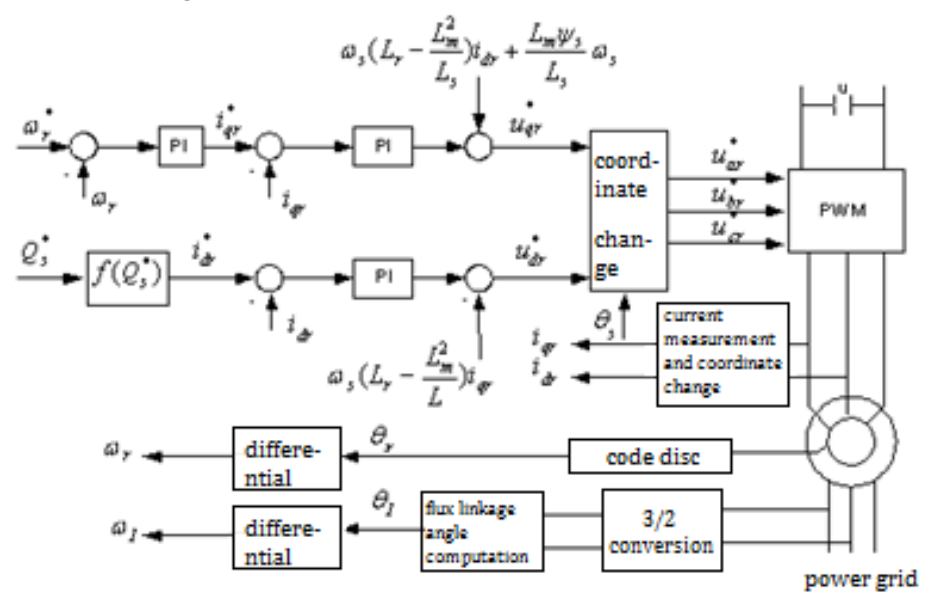

Figure 1. Fan Vector Control

\subsection{All-vanadium Redox Flow Storage Model Building}

VRB uses two rotating liquid pumps to continuously input electrolytic solution stored in the two storage tanks into battery stack and the electrolytic solution flows out of reactor after discharging is over to eliminate concentration polarization. The flowing electrolytic tanks are not only able to increase battery's storage capacity but also to timely increase or replace electrolytic solution when it is necessary.

VRB equivalent circuit is as illustrated in Figure. 2. With the consideration of physical and mathematical characteristics of VRB, its model is as follows: $S_{S O C}$ represents the amount of active chemical substance and it is equivalent in an updated dynamic variable; battery stack potential is equivalent in a controlled voltage source that changes according to changes of $S_{S O C}$. Pump wear is equivalent in a controlled current source that is controlled through pump wear current $I_{P U M P}$ and its value is influenced by $S_{S O C}$ and $I_{P U M P}$.

VRB Simulation Model is as illustrated as follows: 


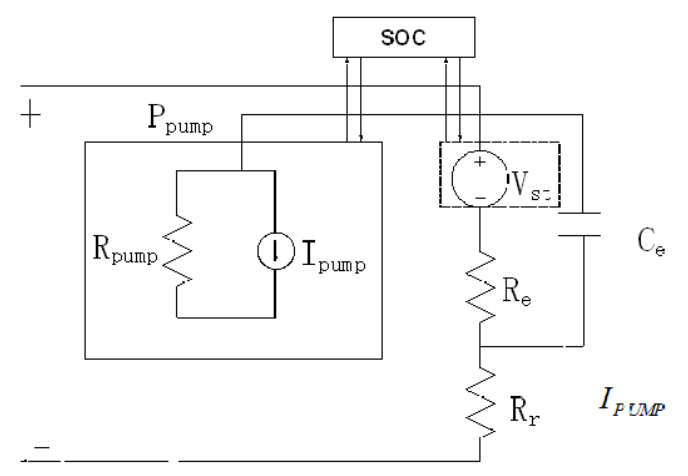

Figure 2. Vrb Equivalent Circuit Model
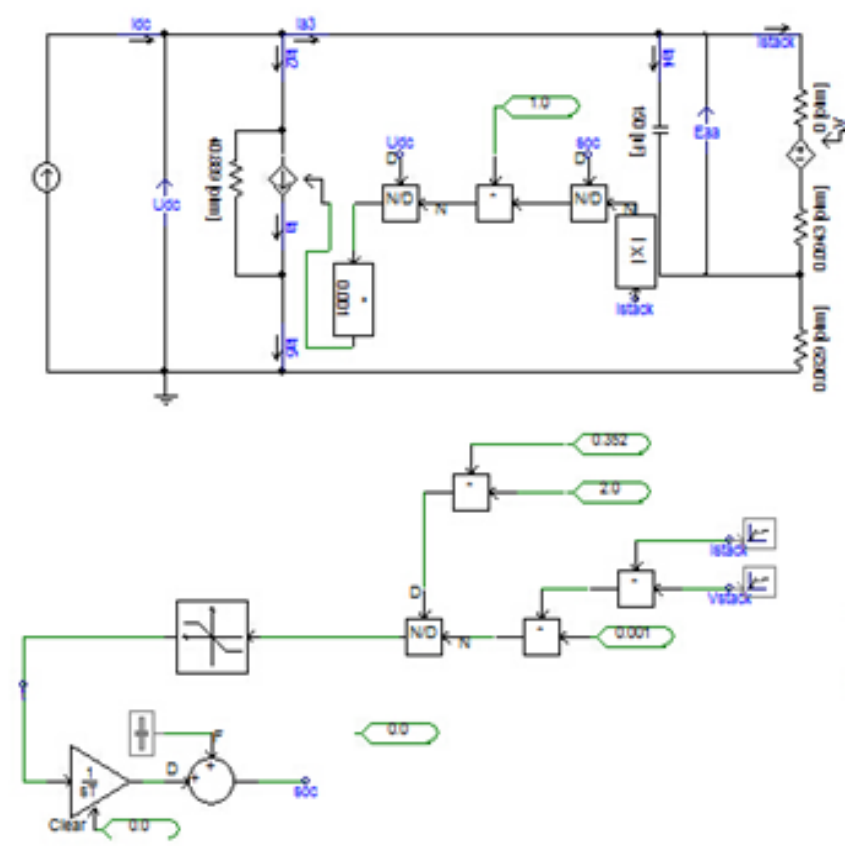

Figure 3. VRB Battery Simulation Model Built In PSCAD

\subsection{Power Storage Inverter Model Building}

It is the study based on RXSV-T Series Power Storage Inverter that uses voltage source type of two-level \& three-phase bridge topological structure as follows:

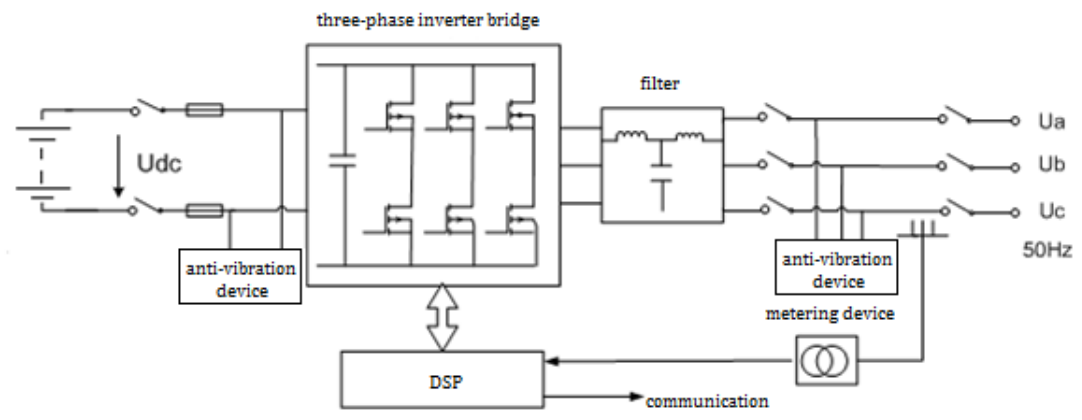

Figure 4. Power Storage Inverter Schematic 


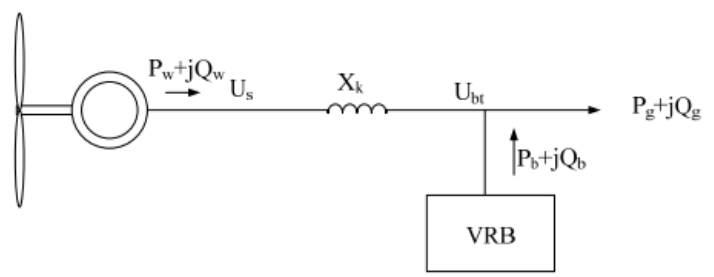

Figure 5. Parallel Power Storage Structural Drawing In AC Side

When inverter is working, $\mathrm{AC}$ breaker is closed first to conduct pre-charging before AC contactor is closed; DSP emits trigger pulse, IGBT starts working and adjusts DC bus voltage. When DC bus voltage is equal to voltage of storage battery, DC contactor is closed, DSP collects signals of DC voltage, DC current, AC voltage and AC current, etc and conducts vector logic computation; inverter outputs necessary active power and reactive power according to system command signal. DSP also conducts real-time judgment of power grid and battery status. When power grid or battery fault is detected, it timely stops working and breaks DC and AC contactors for protection.

\subsection{Wind Storage System Model Building}

Storage system is connected with low-voltage bus through transformer via DC-DC converter and PWM converter. Control system is composed of two parts: Dc-DC double-way converter and DC-AC convertor. Its inner loop control strategy is same as convertor of double-fed asynchronous motor in stator side and it only provides control targets of stable voltage and active power output and control strategy for outer loop electricity.

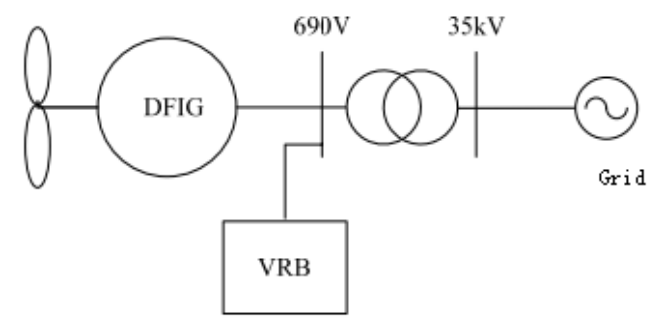

Figure 6. Equivalent Diagram of Storage Accessing Wind Power System

VRB storage system's output power is as follows:

$$
\left\{\begin{array}{c}
P_{b}=\frac{3}{2} u_{s d} i_{s d}=\frac{3}{2} U_{s} i_{s d} \\
Q_{b}=-\frac{3}{2} u_{s d} i_{s q}=-\frac{3}{2} U_{s} i_{s q}
\end{array}\right.
$$

Storage system's double-way AC-DC converter and DC-DC converter control diagram is as illustrated in Figure. 7. 


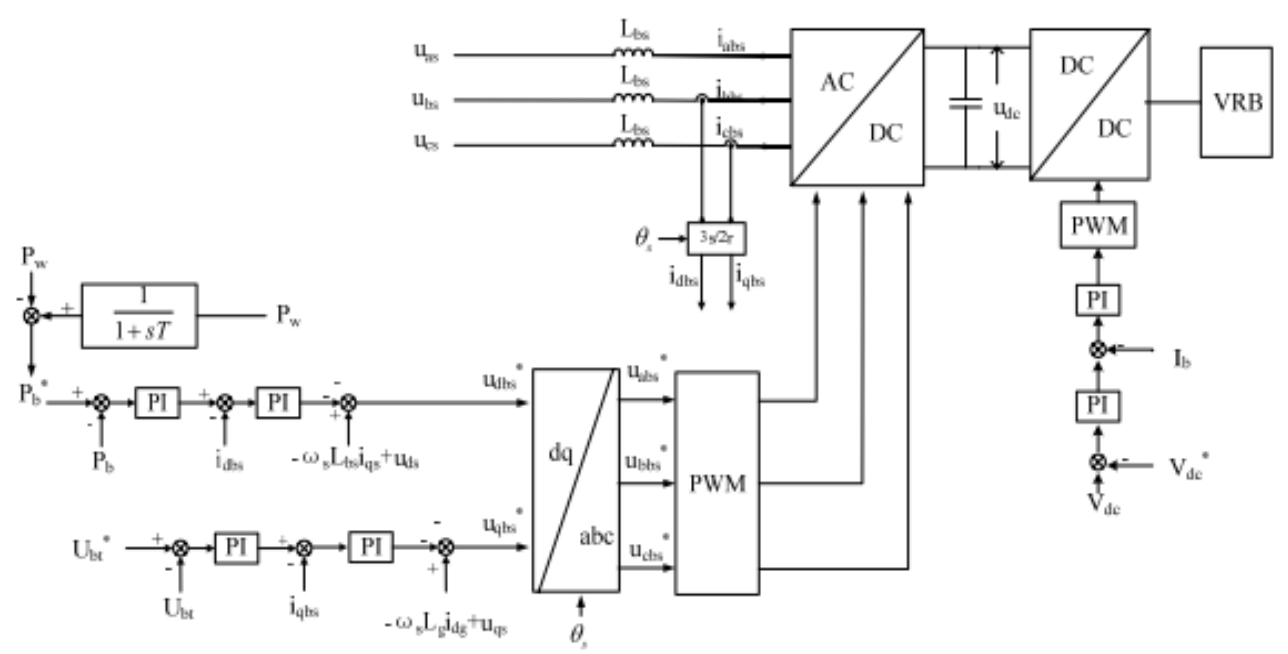

\section{Figure 7. Control Diagram of Storage System's Double-Way AC-DC Converter and DC-DC Converter}

\section{Criterion of Wind Storage System Realizing Black Start}

\subsection{Criterion of Realizing Black Start}

When black start is initiated, fan and power storage constitute the stable isolated system. Nevertheless fan output rate is not stable and it is hard to realize balanced status of wind storage system due to real-time change of wind speed and response time of pitch distance angle change. According to the simulation examples, it is hereby to provide two solutions.

\subsubsection{Criterion of Black Start Scheme One}

In case of large wind speed fluctuation, according to power value $S_{L}$ for standby load and power loss along the line $\Delta S$, it is able to calculate power value $S_{\Sigma}$ required for black start wind field. Based on the judgment of storage capacity $P_{C}$, storage vacancy $P_{C}$ and general power generation amount of the fan at current wind speed, it limits fan output to minimum power generation power at $P_{G 0}$ (wind speed: $2 \mathrm{~m} / \mathrm{s}$ ) and starts $\mathrm{n}$ fans to charge power storage; when the sum of fan power generation amount and storage capacity reaches the desired load value, it starts charging the lines and transformers along the line to realize black start. Reactive power will be compensated by SVC of high-voltage bus in wind field as illustrated in Figure. 8.

$$
\left\{\begin{array}{c}
S_{L}+\Delta S=S_{\Sigma} \\
P_{L}-P_{C}=P_{G} \\
P_{G} / P_{G 0} \leq n
\end{array}\right.
$$




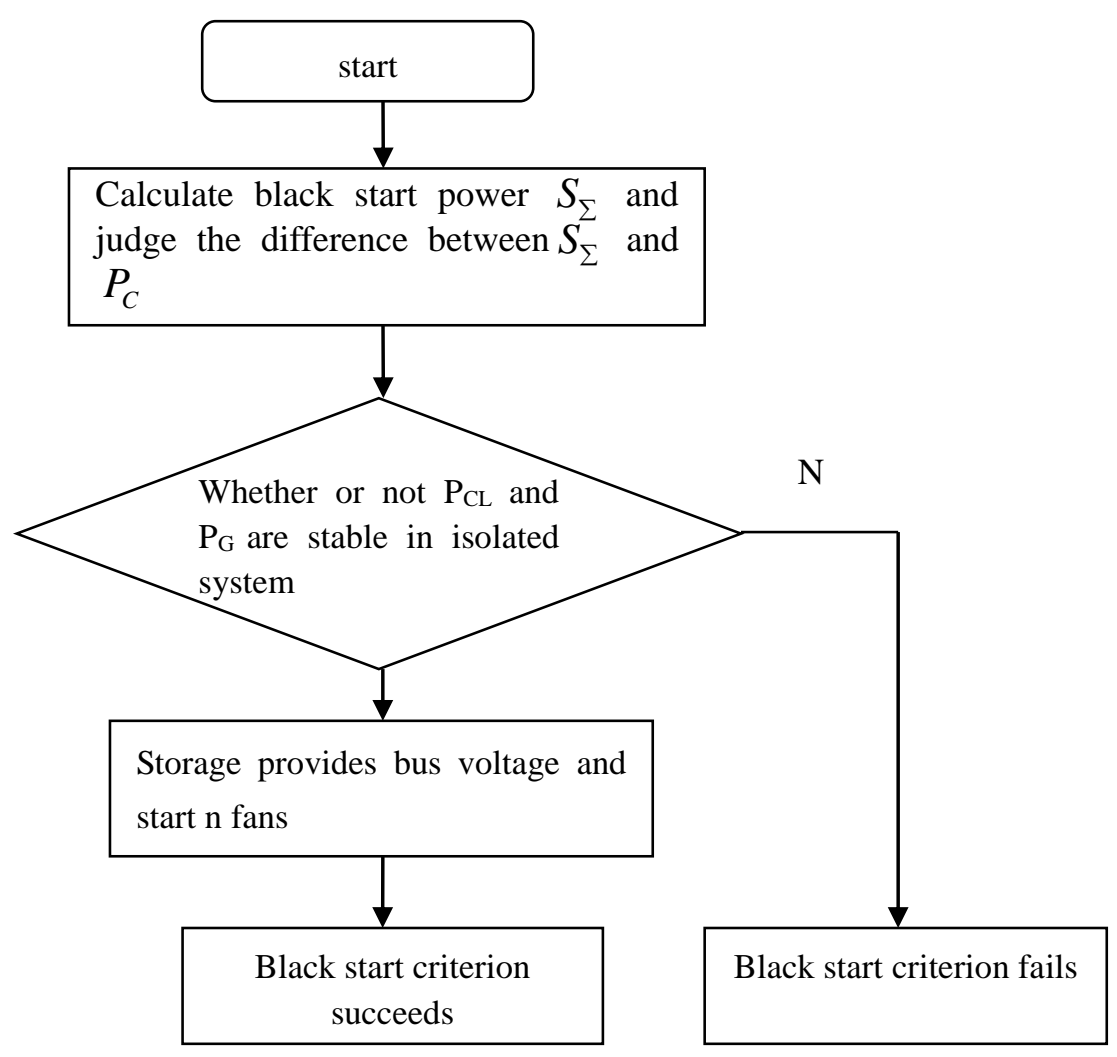

Figure 8. Criterion of Black Start One

\subsubsection{Criterion of Black Start Scheme Two}

In case of small wind speed fluctuation, it is not necessary to limit fan output. Add/unload resistance $\mathrm{R}$ on high-voltage bus to constitute stable isolated system through storage \& wind mechanism and the general fan output $P_{G}$ shall be able to meet with minimum requirement for realizing black start according to the economical requirement of unloading resistance. You shall refer to Formula 3 for the confirmation of $\mathrm{R}$ and refer to Figure. 9 for flow chart.

$$
\left\{\begin{array}{c}
P_{L}-P_{C}=k P_{G} \\
k=(1.1 \square 1.5) \\
P_{G}=P_{G 1}+P_{G 2}+\cdots+P_{G n} \\
R=\frac{U^{2}}{P_{G}-P_{C}}
\end{array}\right.
$$




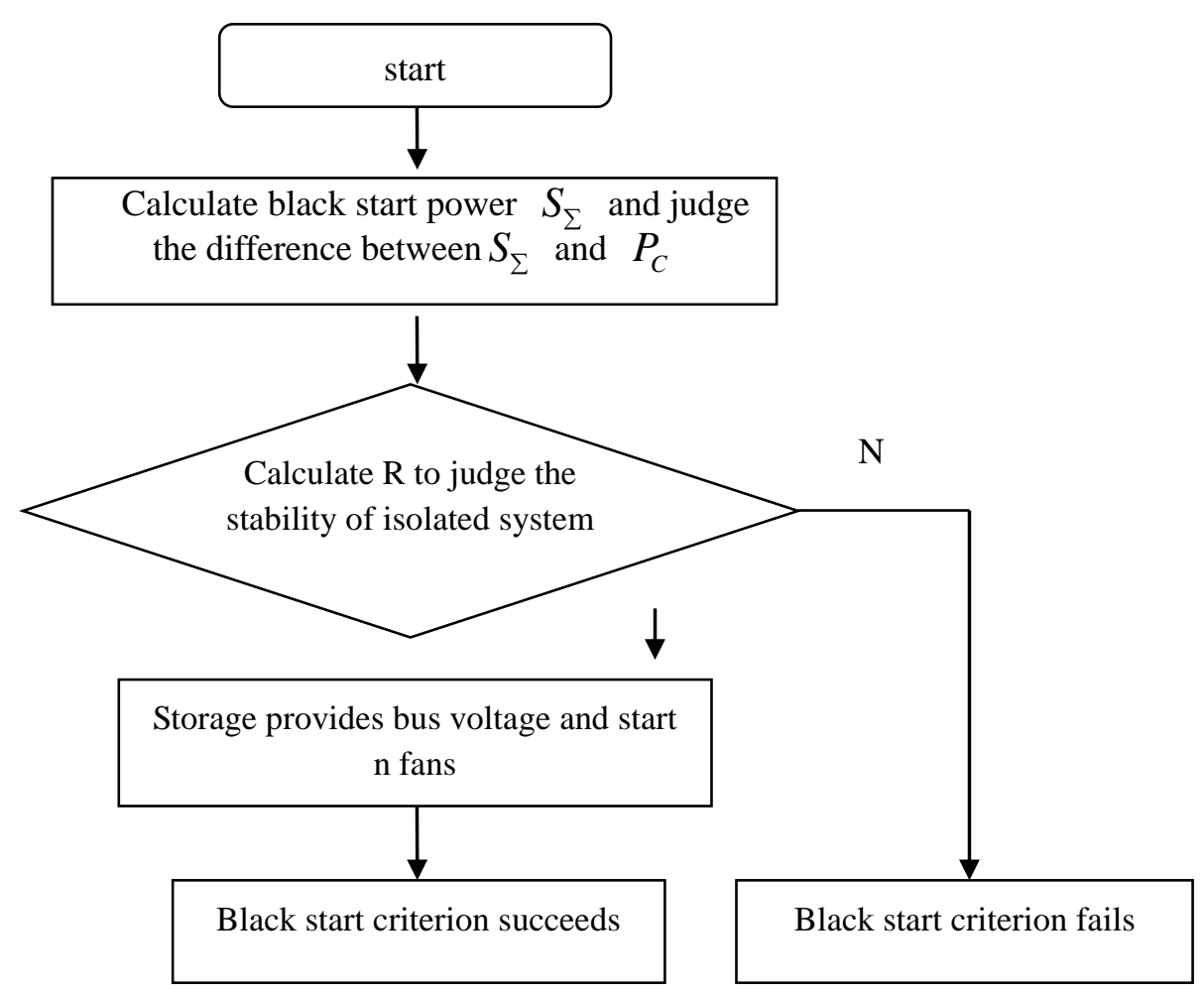

Figure 9. Criterion of Black Start Two

\subsection{Impact Load Treatment}

When black start criterion succeeds, we shall still verify work frequency overvoltage, switching overvoltage, reactive phase and impact load especially for various pumps in standby fire power plants because impact current exists in non-frequency conversion startup.

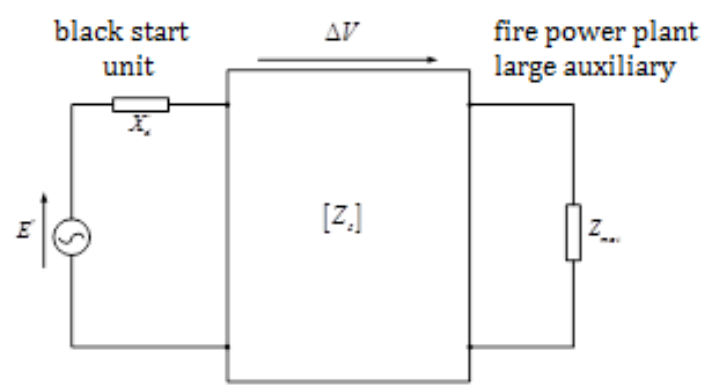

Figure 10. Black Start Unit Remote Start Fire Power Unit's Thevenin's Equivalent Circuit

According to Figure. 10, we can obtain voltage drop and motor output power as:

$$
\begin{gathered}
\Delta V=1-\left|\frac{Z_{m o t}}{Z_{m o t}+Z_{s}+j X_{d}^{\prime \prime}}\right| \\
P_{e}(s)=\operatorname{real}\left(\frac{\sqrt{3} E^{\prime 2}}{Z_{m o t}+Z_{s}+j X_{d}^{\prime \prime}}\right)
\end{gathered}
$$

In the process of starting inductive motor, line will only consume little active power and the inductive motor's power is almost equal to motor's output power. We can obtain 
the average impact power $P_{e l}$ of inductive motor in startup.

$$
P_{e l}=\frac{1}{1-s_{0}} \int_{1}^{s_{0}} P_{e}(s) d s
$$

In the formula, $s_{0}$ indicates initial slip after inductive motor starts running with empty load before the loaded running starts.

\subsection{Black Start Scheme's Overall Flow Chart}

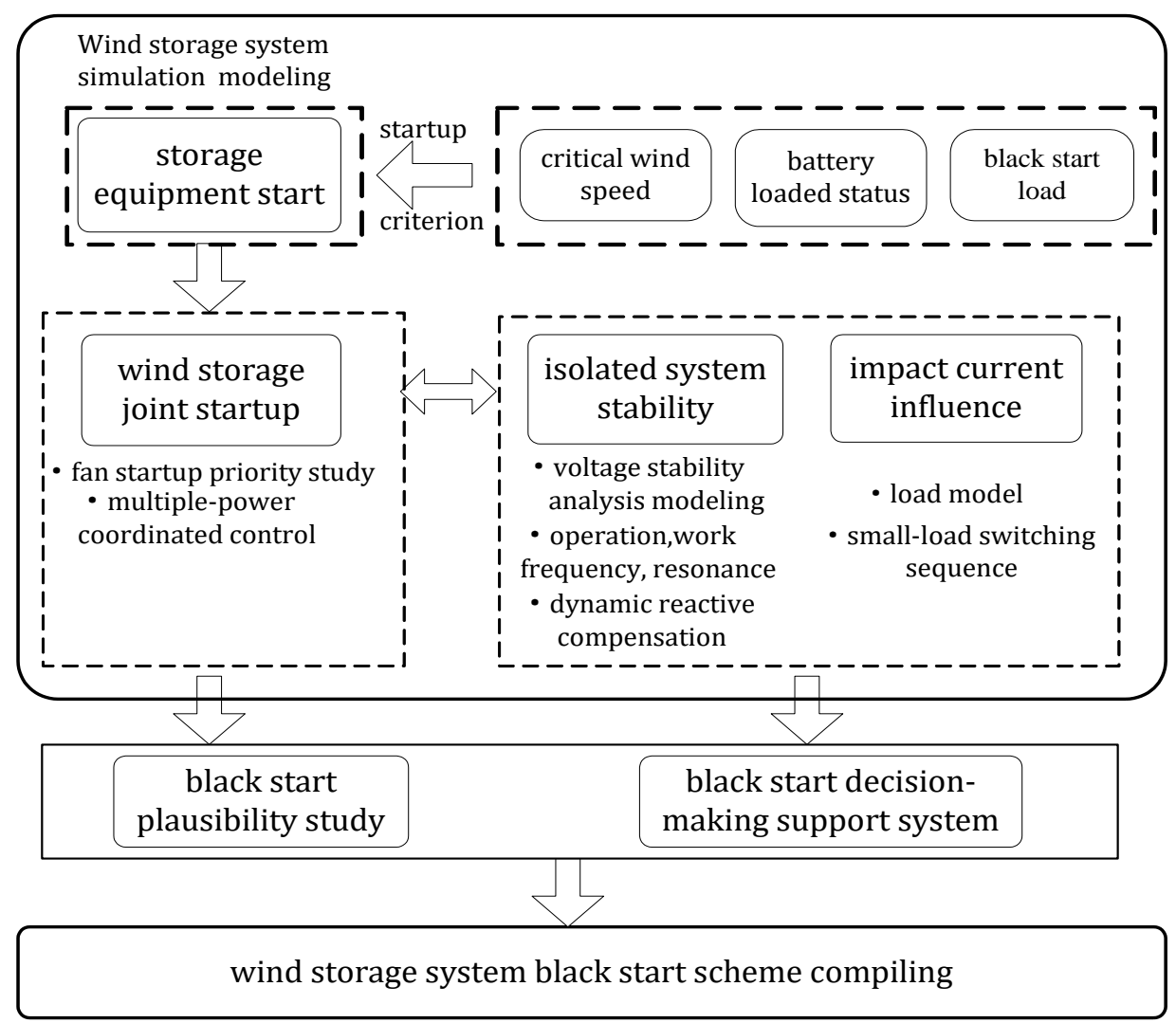

Figure 11. Black Start Scheme's Overall Flow Chart

\section{Simulation Example}

In this paper, it takes Woniushi Wind Power Field in Liaoning Province as its black start power and the standby load is the 5MW water pump in Diaobingshan Power Plant in Liaoning Province. System wiring is as illustrated in Figure. 12. 
Table 1. Wind Field Parameters

\begin{tabular}{|c|c|}
\hline Name of Equipment & Equipment Parameters \\
\hline Fan & $1.5 \mathrm{MW} * 33$ \\
\hline VRB & $\begin{array}{c}5 \mathrm{MW} * 2 \mathrm{~h} \\
\text { Reactive compensation power at 2.5MVar }\end{array}$ \\
\hline $\begin{array}{c}\text { Reactive compensation } \\
\text { device SVC }\end{array}$ & $\begin{array}{c}\text { Capacitor Unit's Capacity 6000kvar } \\
\text { Resistance Unit's Capacity 6012kvar }\end{array}$ \\
\hline $\begin{array}{c}\text { Wind Power Field Main } \\
\text { Transformer }\end{array}$ & SZ11-50000/66*2 \\
\hline $\begin{array}{c}\text { Longkang Transformer } \\
\text { Empty-load loss } 120 \mathrm{~kW} \\
\text { Loaded loss 530kW }\end{array}$ \\
\hline Name of Equipment & Equipment Parameters \\
\hline Fan & $1.5 \mathrm{MW} * 33$ \\
\hline VRB & $5 \mathrm{MW} 2 \mathrm{~h}$ \\
\hline $\begin{array}{c}\text { Reactive compensation } \\
\text { device SVC }\end{array}$ & $\begin{array}{c}\text { Capacitor Unit's Capacity } 6000 \mathrm{kvar} \\
\text { Resistance Unit's Capacity } 6012 \mathrm{kvar}\end{array}$ \\
\hline $\begin{array}{c}\text { Wind Power Field } \\
\text { Main Transformer }\end{array}$ & SZ11-50000/66*2 \\
\hline Longkang Transformer & $\begin{array}{c}240000 \mathrm{kVA} * 3 \\
\text { Empty-load loss } 120 \mathrm{~kW} \\
\text { Loaded loss 530kW }\end{array}$ \\
\hline
\end{tabular}

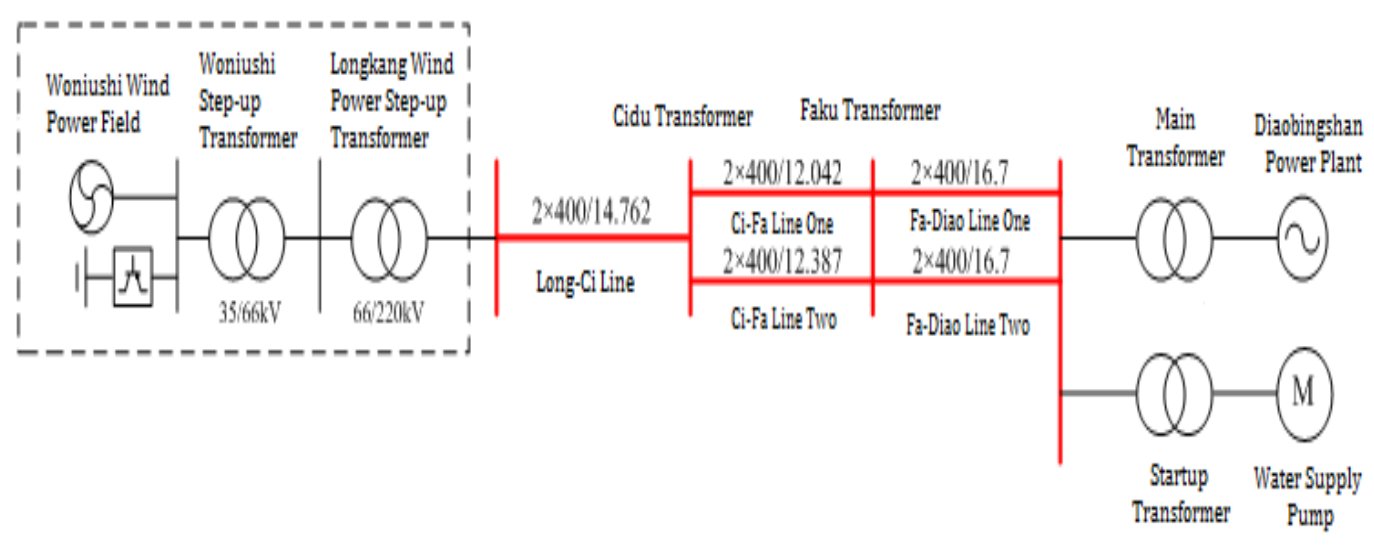

Figure 12. Simulation Example Systematic Diagram

Table 2. Startup Motor Parameters

\begin{tabular}{|c|c|}
\hline & Name of Equipment: YKS800-4 Water Pump Motor \\
\hline Rated Power (KW) & 5200 \\
\hline Rated Voltage (KV) & 6 \\
\hline Rated Current (A) & 564 \\
\hline Stator Resistance & $0.0324 \Omega$ \\
\hline Stator Reactance & $1.168 \Omega$ \\
\hline Rotator Resistance & $0.0342 \Omega$ \\
\hline Rotator Reactance & $1.694 \Omega$ \\
\hline Magnetizing Inductance & $50.3 \Omega$ \\
\hline $\begin{array}{c}\text { Stator/Rotator Leakage } \\
\text { Inductance }\end{array}$ & $2.8611 \Omega$ \\
\hline
\end{tabular}


Based on the analysis of Woniushi Wind Power Field in different typical days (changes of wind speed), the simulation result is as follows:

\subsection{Windy Seasons (large wind speed change)}

Typical conditions in this category cover $55 \%$ in total wind speed data.

Table 3. Wind Storage Isolated Operation Simulation Result (I)

\begin{tabular}{|c|c|c|}
\hline & $\begin{array}{c}\text { Black start } \\
\text { criterion and } \\
\text { startup scheme }\end{array}$ & $\begin{array}{c}\text { Startup fan } \\
\text { amount and } \\
\text { capacity }\end{array}$ \\
\hline & & \\
\hline $\begin{array}{c}\text { Storage capacity } \\
30 \%\end{array}$ & $\begin{array}{c}\text { Success } \\
\text { Scheme Two }\end{array}$ & $\begin{array}{c}\mathrm{n}=5.5-7.5 \mathrm{M} \\
\mathrm{W}\end{array}$ \\
\hline $\begin{array}{c}\text { Storage capacity } \\
50 \%\end{array}$ & Success & $\mathrm{n}=4$ 、 \\
Scheme Two & $3.5-5.5 \mathrm{M}$ \\
\hline $\begin{array}{c}\text { Storage capacity } \\
70 \%\end{array}$ & Success & $\mathrm{W}=2 、$ \\
\hline
\end{tabular}

Table 4. Wind Storage Isolated Operation Simulation Result (II)

\begin{tabular}{|c|c|c|}
\hline $\begin{array}{c}\text { 66KV buss unloading } \\
\text { resistance value }\end{array}$ & $\begin{array}{c}\text { Reactive } \\
\text { compensation }\end{array}$ & $\begin{array}{c}\text { Empty-load overvoltage } \\
\text { upper limit statistics in } \\
\text { each bus }\end{array}$ \\
\hline $1057-4279$ & $-6.3 \mathrm{MVA}$ & $\begin{array}{c}\text { Bus upper limit of Bus in } \\
\text { Faku Transformer }\end{array}$ \\
\hline $987-4355$ & $-5.79 \mathrm{MVA}$ & $\begin{array}{c}\text { Bus upper limit of } \\
\text { High-voltage Bus in Fire } \\
\text { Power Plant }\end{array}$ \\
\hline $3214-4279$ & $-7.04 \mathrm{MVA}$ & $\begin{array}{c}\text { Bus upper limit of Bus in } \\
\text { Faku Transformer }\end{array}$ \\
\hline
\end{tabular}

Table 5. Standby Motor Simulation Result

\begin{tabular}{|c|c|c|c|c|c|}
\hline & $\begin{array}{c}\text { Storage } \\
\text { Charging } \\
\text { Time }\end{array}$ & $\begin{array}{c}\text { Storage } \\
\text { Capacit } \\
\mathrm{y}\end{array}$ & $\begin{array}{c}\text { Reactive } \\
\text { Compensatio } \\
\mathrm{n}\end{array}$ & $\begin{array}{c}\text { Frequency-conv } \\
\text { erted Startup }\end{array}$ & $\begin{array}{c}\text { Non-frequency } \\
\text {-converted } \\
\text { Startup }\end{array}$ \\
\hline $\begin{array}{c}\text { Storage } \\
\text { capacity 30\% }\end{array}$ & $13 \mathrm{MIN}$ & $67 \%$ & $10.3 \mathrm{MVA}$ & Succeed & Fail \\
\hline $\begin{array}{c}\text { Storage } \\
\text { capacity 50\% }\end{array}$ & $9 \mathrm{MIN}$ & $74 \%$ & $9.78 \mathrm{MVA}$ & Succeed & Fail \\
\hline $\begin{array}{c}\text { Storage } \\
\text { capacity } 70 \%\end{array}$ & $4 \mathrm{MIN}$ & $83 \%$ & $9.04 \mathrm{MVA}$ & Succeed & Fail \\
\hline
\end{tabular}

\subsection{Windy Seasons (small wind speed change)}

Typical conditions in this category cover $15 \%$ in total wind speed data. 
Table 6. Wind Storage Isolated Operation Simulation Result (I)

\begin{tabular}{|c|c|c|}
\hline & $\begin{array}{c}\text { Black start criterion } \\
\text { and startup scheme }\end{array}$ & $\begin{array}{c}\text { Startup fan amount } \\
\text { and capacity }\end{array}$ \\
\hline $\begin{array}{c}\text { Storage capacity } \\
30 \%\end{array}$ & $\begin{array}{c}\text { Success } \\
\text { Scheme One }\end{array}$ & $\mathrm{n}=10,3 \mathrm{MW}$ \\
\hline $\begin{array}{c}\text { Storage capacity } \\
50 \%\end{array}$ & $\begin{array}{c}\text { Success } \\
\text { Scheme One }\end{array}$ & $\mathrm{n}=7,2.1 \mathrm{MW}$ \\
\hline $\begin{array}{c}\text { Storage capacity } \\
70 \%\end{array}$ & $\begin{array}{c}\text { Success } \\
\text { Scheme One }\end{array}$ & $\mathrm{n}=4,1.2 \mathrm{MW}$ \\
\hline
\end{tabular}

Table 7. Wind Storage Isolated Operation Simulation Result (II)

\begin{tabular}{|c|c|c|}
\hline $\begin{array}{c}\text { 66KV buss unloading } \\
\text { resistance value }\end{array}$ & $\begin{array}{c}\text { Reactive } \\
\text { compensation }\end{array}$ & $\begin{array}{c}\text { Empty-load overvoltage upper } \\
\text { limit statistics in each bus }\end{array}$ \\
\hline Non-invested & $-6.1 \mathrm{MVA}$ & $\begin{array}{c}\text { Bus upper limit of Bus in Faku } \\
\text { Transformer }\end{array}$ \\
\hline Non-invested & $-4.3 \mathrm{MVA}$ & $\begin{array}{c}\text { Bus upper limit of High-voltage } \\
\text { Bus in Fire Power Plant }\end{array}$ \\
\hline Non-invested & $-5.17 \mathrm{MVA}$ & $\begin{array}{c}\text { Bus upper limit of Bus in Faku } \\
\text { Transformer }\end{array}$ \\
\hline
\end{tabular}

Table 8. Standby Motor Simulation Result Windy Seasons (Small Wind Speed Change)

\begin{tabular}{|c|c|c|c|c|c|}
\hline & $\begin{array}{c}\text { Storage } \\
\text { Charging } \\
\text { Time }\end{array}$ & $\begin{array}{c}\text { Storage } \\
\text { Capacity }\end{array}$ & $\begin{array}{c}\text { Reactive } \\
\text { Compensation }\end{array}$ & $\begin{array}{c}\text { Frequency-converted } \\
\text { Startup }\end{array}$ & $\begin{array}{c}\text { Non-frequency-converted } \\
\text { Startup }\end{array}$ \\
\hline $\begin{array}{c}\text { Storage } \\
\text { capacity } \\
30 \%\end{array}$ & $15 \mathrm{MIN}$ & $80 \%$ & $10 \mathrm{MVA}$ & Succeed & Fail \\
\hline $\begin{array}{c}\text { Storage } \\
\text { capacity } \\
50 \%\end{array}$ & $9 \mathrm{MIN}$ & $80 \%$ & $9 \mathrm{MVA}$ & Succeed & Fail \\
\hline $\begin{array}{c}\text { Storage } \\
\text { capacity } \\
70 \%\end{array}$ & $13 \mathrm{MIN}$ & $80 \%$ & $9.74 \mathrm{MVA}$ & Succeed & Fail \\
\hline
\end{tabular}

\subsection{Seasons with Less Wind}

Typical conditions in this category cover $35 \%$ in total wind speed data.

Table 9. Wind Storage Isolated Operation Simulation Result (Seasons with Less Wind)

\begin{tabular}{|c|c|c|}
\hline & $\begin{array}{l}\text { Black start criterion and } \\
\text { startup scheme }\end{array}$ & Reasons \\
\hline Storage capacity $30 \%$ & Non-successful & \multirow{3}{*}{$\begin{array}{l}\text { Over-long charging time does } \\
\text { not meet with black start } \\
\text { condition for two hours. }\end{array}$} \\
\hline Storage capacity $50 \%$ & Non-successful & \\
\hline Storage capacity $70 \%$ & Non-successful & \\
\hline
\end{tabular}

\section{Conclusion}

This paper fully analyzes the possibility of wind power plant possessing large-capacity all-vanadium redox flow power storage equipment as the black start power for the full grid. When conditions meet with requirements such as external wind power and storage charging amount, etc, wind storage joint power generation system possesses the black start ability. We shall focus on the fact that if there is no unloading resistance, high value 
of storage charging amount in isolated system will limit fan output and it is not good for the rapid realization of black start. Based on simulation computation, the optimum rate at $5-\%$ to $60 \%$ when black start is initiated. If there is unloading resistance, the higher the storage power is, the faster the black start will be realized. Nevertheless it has also higher requirement for unloading resistance with bad economic performance. Therefore it is not good for the promotion of wind storage as black start power supply.

In this paper, it compiles the complete black start control strategy and start scheme. Based on the realistic data of Liaoning Power Grid, it builds simulation model to verify the reasonability of the control strategy and start scheme provided in this paper. Simulation data indicate that under certain conditions wind storage joint power generation system is able to be used as black start power supply. The study in this paper is not only favorable for promoting the development and application of clean energy technology and power storage technology, but also contains realistic meaning in solving black star problem in areas without water and electricity, and improving the power grid's ability in defending power failure in large area.

\section{References}

[1] X. P. Meng, L. Yao and J. K. Lin, "Tianjin Power Grid Black Start Scheme", Electric Power Automation Equipment, vol. 28, no. 108, (2010).

[2] J. H. Li, Q. L. Ni and X. H. Jin, "Zhejiang Power Grid Black Start Scheme Compilation Study”, East China Power, vol. 34, no. 26, (2010).

[3] C. Zhou and Y. C. Liao, "Discussion Over Hechi Power Grid Black Start Scheme in Guangxi Province", Guangxi Power, vol. 2, no. 58, (2013).

[4] L. Wang, "Black Start in Sudan Power Grid", Heilongjiang Power, vol. 27, no. 446, (2013).

[5] B. Delfmo, G. B. Denegri and M. Invernizzi, "Black-Start and Restoration a part of the Italian HV Network: Modeling and Simulation of field Test", IEEE Transactions on Power Systems, vol. 11, no. 1391, (2011).

[6] D. S. Kirschen and T. L. Volkmann, "Guiding a Power System Restoration with an Expert System", IEEE Transactions on Power Systems, vol. 6, no. 558, (2012).

[7] V. W. Ivan and Hunt, "Diesel Engine Generators Block Start and Supply Emergencies", Electrical Engineers Association Annual Conference. Auckland, vol. 16, no. 17, (2012).

[8] S. Y. Yang, "Study on Double-fed Wind Power Generation Convertor Control Machine Strategy", Hefei University of Technology, (2007).

[9] CIGRE Study Committee. "Modelling and Simulation of Black Start and Restoration of Electric Power Systems", Electra, (1993).

[10] M. M. Adibi, P. Clelland and L. Fink, "Power System Restoration:a Task Force Report”, IEEE Trans on Power Systems, vol. 2, no. 927, (1987).

[11] B. Delfino, G. B. Denegri and M. Invernizzi, "Black Start and Restoration of a part of the Ltalian HV Network: Modelling and Simulation of a Field Test”, IEEE Transactions On Power Systems, vol. 11, no. 1371, (1996).

[12] J. Y. Guo, T. Wu and R. W. Zhang, "Test and Research of Black Start in North China Power Network", North China Electric Power, vol. 5, no. 1, (2001)

[13] C. Y. Wang, H. T. Wang and Y. T. Liu, "Black Start Scheme Production and Training Simulation in DTS", Electric Power Automation Equipment, vol. 29, no. 122, (2009).

[14] S. H. Peng and Z. L. Ju, "The Analysis of the Chenzhou Electfical network Black Start during the Ice Disaster Peiiod", Central China Electric Power, vol. 21, no. 53, (2008).

[15] H. Bludszuweit and J. A. Dominguez-Navarro, "A Probabilistic Method for Energy Storage Sizing based on Wind Power Forecast Uncertainty”, IEEE Trans on Power Systems, vol. 26, no. 1651, (2011). 


\section{Authors}

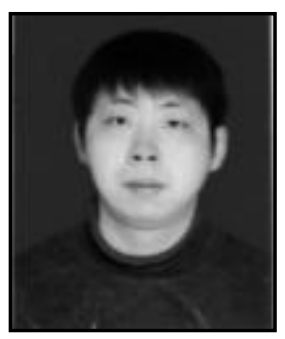

Gang Wang, he received the M.S degree in Power System and Automation from Northeast Electric Power University, Changchun, China, in 2008. His research interests include power system and automation.

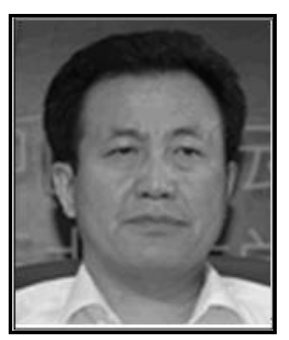

Jianchang Liu was born in 1960. Ph.D., Professor, doctoral tutor, doctor, lecturer. His main research directions include intelligent control theory and application, the complex system modeling, control and optimization.

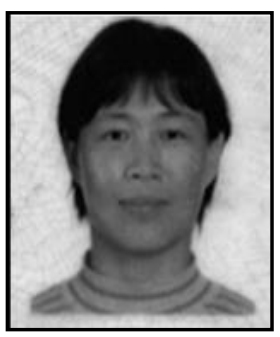

Li Liu wan born in 1963. She is a professor in Shenyang Institute of Engineering. Her main research direction is distribution network related computing.

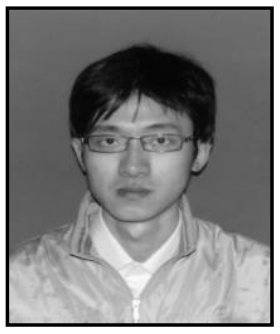

Yi Zhao received the M.S degree in Power System and Automation from Liaoning Project Technology University, Fuxin, China, in 2008. His research interests include Power flow calculation and control. 